\title{
Teaching Practice
}

\section{Guidance for Learners' Improvement of Speaking Skills}

\author{
Doan Linh Chi \\ Nha Trang Teachers Training College, Vietnam
}

\begin{abstract}
Practice is considered an important part of language learning. Students are always encouraged to practice as much and as often as possible. However, some students do not know how to practice well and feel disappointed as practice does not always help them make much progress in their studies. Thus, as teachers, we should give them guidance on effective practice. This paper reports what and how guidance for practice should be provided for effective improvement of students' speaking skills. Encouraging preliminary results show that a set of appropriate activities to practice speaking and good management of group work can enhance students' speaking skills and increase their autonomy.
\end{abstract}

Practice is a language learning strategy that learners use to enhance their learning. Learners who want to make progress in their study often spend as much time as possible practicing the skills which need improvement. However, for many English majors at Nha Trang Teachers Training College, much practice does not equate to success.

According to Renandya (2010), only perfect practice makes perfect. This implies that students might not be practicing well. What should teachers do to help students practice well? What guidance is needed? In this paper, the author would like to offer some guidance to enhance students' practice of speaking skills. The main reason why speaking was chosen is

... of all the four skills (listening, speaking, reading and writing), speaking seems intuitively the most important: people who know the language are referred to as "speakers" of that language, as if speaking included all other kinds of knowing; and many if not most foreign language learners are primarily interested in learning to speak. (Ur, 1996, p. 120)

The guidance was a lesson from a small-scale project applied to first and second-year students at Nha Trang Teachers Training College in the academic years 2009-2010 and 2010-2011.

Language Education in Asia, 2011, 2(2), 213-226. http://dx.doi.org/10.5746/LEiA/11/V2/I2/A04/Doan 


\section{Theoretical Background}

\section{Teachers' Roles}

The main goal of teaching speaking is communicative efficiency. Teaching speaking means helping learners develop their ability to interact successfully in the target language. To do so, one must have communicative competence. Richards, Platt, and Weber (as cited in Nunan, 1999, p. 226) defined the characteristics of communicative competence as:

... (a) knowledge of the grammar and vocabulary of the language; (b) knowledge of rules of speaking (e.g., knowing how to begin and end conversations, knowing what topics can be talked about in different types of speech events, knowing which address forms should be used with different persons one speaks to and in different situations); (c) knowing how to use and respond to different types of speech acts such as requests, apologies, thanks, and invitations; (d) knowing how to use language appropriately. (p. 226)

Thus, to help students enhance their speaking skills, the teacher must help students improve their grammar, enrich their vocabulary, and manage interactions in terms of who says what, to whom, when, and about what.

Byrne (1987) stated that developing students' ability to interact successfully in the target language is a gradual process that begins with letting them imitate a model or respond to cues. Therefore, the same type of speaking activity might be practiced several times during the skill acquisition process; however, the task requirements should be of increasing levels of difficulty.

\section{Why Group Work?}

Many language classes are big, with students of differing abilities. This is a real obstacle for teachers striving to help students improve their speaking skills. In this case, group work has proved to be an effective way to solve the problem as "... group work allows all students to practise language and to actively participate" (Baker \& Westrup, 2000, p. 131). Group work is highly recommended by many experts as a useful technique to get students involved in classroom activities, increase student talking time, and reduce teacher talking time (Brumfit, 1984; Harmer, 1991; Nation, 1989; Petty, 1993). More than a simple classroom technique, "it has been considered one of the major changes to the dynamics of the classroom interaction brought by student-centered teaching" (Nunan \& Lamb, as cited in Le, 2010, p. 2). The benefits of group work are recognized not only by language teachers and experts, but also by language students: ". . I began to see the benefits of participating in group work. I could improve my communication skills in the target language, develop my skills in cooperating with group members, and learn new ideas from others" (Qiangba, 2005, p. 48).

\section{Popular Speaking Activities}

Kayi (2006) studied popular speaking activities and analyzed their advantages. She recommends the following activities:
Discussions
Role-play
Simulations
Information Gap

\author{
Brainstorming \\ Storytelling \\ Interviews \\ Story Completion
}

\author{
Reporting \\ Playing Cards \\ Picture Narrating \\ Picture Describing \\ Find the Difference
}


In the three volumes of Communication Games by Hadfield (1996a, 1996b, 1996c), a variety of communicative games and speaking activities provide not only "concentrated practice as a traditional drill," but also "opportunit[ies] for real communication, albeit within artificially defined limits" (1996a, p. iii). In addition to the games and activities recommended by Kayi and Hadfield, language teachers can easily access the rich source of communicative games and speaking activities on the Internet. Whatever the games and activities are named and however they are done, they serve to enhance learners' oral fluency. The teacher's task here is to try to utilize games and activities in such a way that each is exploited to the fullest. To achieve this, flexibility in using games and activities is vital.

\section{Project Background}

The researcher was responsible for teaching speaking and listening skills to 32 first-year college students in the academic year of 2008-2009. For many of them, communicating in a foreign language was unfamiliar. Whenever they wanted to speak, they wrote the sentence they wanted to say and then read it.

A variety of speaking activities was used and group work was applied. However, less progress in oral communication was made than had been expected. There were two kinds of students who were unsuccessful in terms of ability to communicate in English in classroom practice: those who spoke naturally and with fluency usually made a lot of grammar and pronunciation mistakes, and those who made fewer grammar and pronunciation mistakes were not fluent and their speech did not sound natural. Moreover, turn-taking was a problem when students conducted conversations. Those who started a conversation by asking questions would continue doing so to the end of the conversation and those who answered questions did not ask questions. Informal talks conducted with the students revealed the causes of unsuccessful communication were phonological problems, lack of vocabulary, insufficient practice of grammatical and functional structures, and the habit of translating everything from English into the mother tongue and vice-versa when communicating in English.

To help students become better at speaking means to help them gain communicative competence and reduce the number of mistakes they make. In this particular case, the focus was to help students improve their pronunciation, enrich their vocabulary, frequently practice grammatical and functional patterns, and form the habit of thinking in English. To provide guidance for practice, the teacher had to find a way to help students enhance their speaking skills. As a result, in the academic year 2009-2010, a two-year project to help students improve their speaking skills began with 28 first-year students.

\section{The Project}

The project was divided into two phases: guided practice for first-year students, and lessguided practice for second-year students. The teacher had to direct students' practice, evaluate their abilities, form and reform groups, identify common mistakes students made, choose or design speaking activities and communicative games, collect frequent feedback from students, and make timely adjustments as needed. The students had to identify their own problems, set their goals for practice, and work in groups.

\section{Setting Goals to Enhance Speaking Skills}

In the first class session, an overall guidance for students to enhance their own speaking skills was given. A list of common speaking problems was provided. The students were asked to tick their problems and write suggestions (see Appendix A). All 28 students indicated that they 
had problems with the first five items: being unable to remember words or phrases, making grammar mistakes when speaking, making pronunciation errors, thinking in Vietnamese and then translating into English, and being unable to express their ideas well. The students were able to give suggestions on the first three problems; however, they could not suggest solutions for the last two. These two problems are, in fact, closely related to each other. Once students are able to think in English, they will have no difficulty expressing their ideas. Thus, helping students form the habit of thinking in English has primary importance.

The students were given a worksheet to set their own weekly goals (see Appendix B). In the first column, they wrote what they wanted to learn by heart or practice more. In the second column, they noted mistakes they wanted to correct. The mistakes were pointed out by the teacher, by their classmates, or recognized by themselves. The students' goals were different, depending on individual needs. Setting small goals helped the students move step-by-step towards general improvement in speaking and helped strengthen their self-confidence. In a sense, setting goals can be considered to be planning one's practice. This was done throughout the academic year.

Thus, identifying problems and giving suggestions helped the students know exactly what they had to handle when practicing speaking. Having set the goals, the students would pay attention to areas that they wanted to improve. Students were asked to practice as often as possible with their classmates and students from neighboring and upper classes on the following principles: from simple to complicated, less to more, prepared to unprepared speech, and inside to outside class.

\section{Assigning Groups to Enhance Speaking Skills}

Organizing group work. To make practice effective, student collaboration is important. Good collaboration partly depends on the way students are arranged in groups. Dominance by more-able students and passiveness by less-able students as well as increases in the gap between more-able and less-able students should be avoided. Groups should encourage equal participation, help less-able students be self-confident, motivate the more-able students, and make all students be responsible for what they are doing.

Group formation was only done after the first four weeks of study and was based on the teacher's observations. The observations helped in evaluating students' abilities and in knowing, to some extent, students' personalities and relationships. The 28 students had different levels of language proficiency. All were friendly and helpful, and got along well with each other. They were numbered according to their ability from the most able (Student 1 ) to the least able (Student 28) and placed into seven groups (Table 1).

To avoid dominance by the more-able students, each student in Column A of Table 1 was the group leader and had to manage and help all the members in the group. This may seem as if there was too much work for the group leaders and no chance for them to speak when they worked with less-able students. In fact, they were able to practice speaking English as the other group members did. They shared their ideas with their group and helped less-able students express their ideas. It was important that the group leaders were aware of giving speaking opportunities to all group members.

In the first round of group work, real communication could not be achieved. This round was like the preparation of "ingredients" for a real conversation later ("real conversation" here is confined to classroom practice). 
Table 1

\section{Group Assignments}

\begin{tabular}{|l|l|l|l|l|}
\hline Group & A & B & C & D \\
\hline Rose & S1 & S8 & S21 & S28 \\
\hline Daisy & S2 & S9 & S20 & S27 \\
\hline Sunflower & S3 & S10 & S19 & S26 \\
\hline Daffodil & S4 & S11 & S18 & S25 \\
\hline Carnation & S5 & S12 & S17 & S24 \\
\hline Lily & S6 & S13 & S16 & S23 \\
\hline Tulip & S7 & S14 & S15 & S22 \\
\hline
\end{tabular}

(S = Student)

To maintain the interest of more-able students as well as to create more chances for less-able students to practice, there was a second round of the group speaking activity. Groups were reformed. All students in Column A of Table 1 worked together, as did the students in Columns B, C, and D. The new groups had no leaders. The emphasis was on fluency and naturalness of speech. The less-able students, with the "prepared ingredients," were able to manage the practice themselves, so they gained confidence.

Language teachers usually have problems arranging students in groups: ". . the biggest problem is one of selection of group members" (Harmer, 1991, p. 246). Should students work in groups with members of differing language abilities or should they work in groups with members of similar abilities? The practice in this study demonstrated that mixed-ability groups helped less-able students improve and gain more confidence and raised the more-able students' responsibilities (in a sense, more-able students shared the teacher's work in class). However, the success of the mixed-ability groups could only be achieved because the moreable students were clear about their role from the beginning of the course and were willing to help their peers. Groups of similar language abilities motivated the more-able students; the less-able students were successful in such groups only when they had guided practice beforehand.

When working in groups with speaking activities in which monologues were preferable (storytelling, picture narrating, reporting, picture describing), the students were encouraged to recognize their classmates' mistakes (see Appendix C) without giving any comments or corrections until their friends finished their talks. The group leaders recorded all the mistakes recognized by the group and reported them to the teacher. The teacher circulated to give help while the students were working. With speaking activities in which conversations took place, there was no emphasis on recognizing and correcting classmates' mistakes as this might interrupt the flow of conversation.

Being able to identify errors had an advantage: the students could reduce their own mistakes. The students were given the list of "often-made" mistakes and asked to pay attention to avoiding them whenever they practiced speaking. A question might be raised: if students tried to be conscious of avoiding errors when speaking, could they have real communication? The reality was that they could not at first; however, at the end of the first year, the students were making fewer mistakes when they spoke and they were improving at communicating with structures they had learnt. 
One problem language teachers may worry about when managing group work is the students' use of their mother tongue. This could not be totally avoided; nevertheless, the teacher was able to reduce mother tongue usage by giving clear instructions for the tasks and "jumping in" in time to help the students.

Selecting speaking activities. Activities and role-plays from course books and the Internet were used. Appropriateness to the students' level of speaking was always taken into consideration. For first-year students, the activities involved repetition / imitation, whereas the activities for second-year students required more creativity on their part.

Many activities were used for both first-year and second-year students (see Appendix D); however, the levels of difficulty and the requirements were different (see Figure 1 and Table 2).

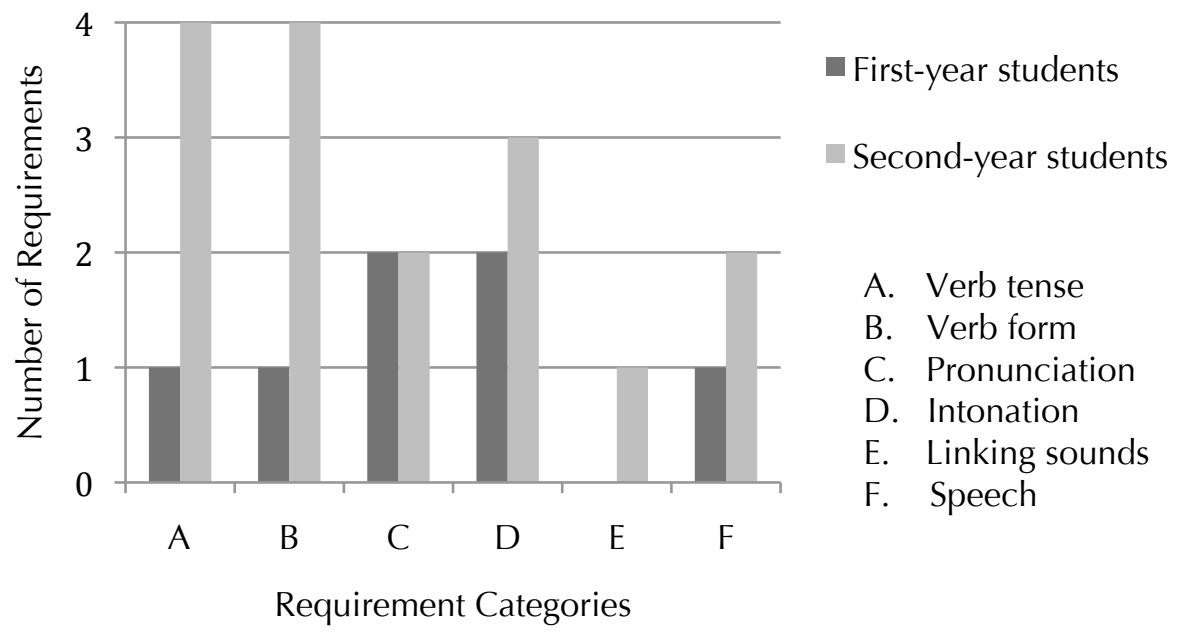

Figure 1. The requirement categories for the same type of speaking activity for first-year students in their first term and for second-year students in their fourth term in the project. The number of requirements gradually increased from the first to the fourth term. 
Table 2

Interview Activity Requirements for $1^{\text {st }}$ and $2^{\text {nd }}$ Year Students

\begin{tabular}{|c|c|}
\hline $\begin{array}{c}\text { First-Year Students } \\
\text { Term } 1 \\
\end{array}$ & $\begin{array}{c}\text { Second-Year Students } \\
\text { Term } 4 \\
\end{array}$ \\
\hline $\begin{array}{l}\text { Activity: Interview your friend about his / her } \\
\text { last holiday. }\end{array}$ & $\begin{array}{l}\text { Activity: Interview your friend about his / her } \\
\text { learning English. }\end{array}$ \\
\hline Requirements: & Requirements: \\
\hline $\begin{array}{l}\text { A. Correct verb tense } \\
\text { 1. Simple past }\end{array}$ & $\begin{array}{l}\text { A. Correct verb tenses } \\
\text { 1. Simple past } \\
\text { 2. Simple present } \\
\text { 3. Present perfect } \\
\text { 4. Present continuous }\end{array}$ \\
\hline $\begin{array}{l}\text { B. Correct verb form } \\
\text { 1. Simple past }\end{array}$ & $\begin{array}{l}\text { B. Correct verb forms } \\
\text { 1. Simple past } \\
\text { 2. Simple present } \\
\text { 3. Present perfect } \\
\text { 4. Present continuous }\end{array}$ \\
\hline $\begin{array}{l}\text { C. Correct pronunciation } \\
\text { 1. Simple past of regular verbs } \\
\text { 2. Simple past of irregular verbs }\end{array}$ & $\begin{array}{l}\text { C. Correct pronunciation } \\
\text { 1. Simple past of regular verbs } \\
\text { 2. Simple past / past participle of } \\
\text { irregular verbs }\end{array}$ \\
\hline $\begin{array}{l}\text { D. Correct intonation } \\
\text { 1. Yes / No questions } \\
\text { 2. Wh- questions }\end{array}$ & $\begin{array}{l}\text { D. Correct intonation } \\
\text { 1. Yes / No questions } \\
\text { 2. Wh- questions } \\
\text { 3. Choice questions }\end{array}$ \\
\hline $\begin{array}{l}\text { F. Speech } \\
\text { 1. Good turn-taking }\end{array}$ & $\begin{array}{l}\text { E. Linking sounds } \\
\text { F. Speech } \\
\text { 1. Good turn-taking } \\
\text { 2. Smooth speech }\end{array}$ \\
\hline
\end{tabular}

To make improvements in using grammatical and functional patterns, frequent out-of-class practice was encouraged. As homework to practice learnt structures, the students brainstormed ten questions per week on topics suggested by the teacher and the students. The topics were simple (e.g., family, job, hobbies) in their first year and more complicated (e.g., campus life, environmental problems, poverty) in their second year. The teacher collected and corrected the questions. This gave the teacher an opportunity to see what mistakes were common, and what remedy could be applied. With the teacher's comments, the students themselves were gradually able to learn how to generate questions and avoid making mistakes. More importantly, the students saw the teacher's effort in helping them to enhance their speaking skills. In return, they studied harder.

After receiving feedback from the teacher, the students were asked to memorize their questions and to practice asking and answering questions with as many students as possible, whenever and wherever they could. Once a month, the teacher randomly selected a prepared topic, and the students practiced asking and answering questions on the topic in class. 
This activity was a simple drill, but it helped students to eradicate the habit of thinking of questions and answers in Vietnamese and then translating them into English when communicating. The more often the questions and answers were practiced, the more deeply they became rooted in the students' minds. Moreover, this activity helped the students to organize their ideas as they were required to put the questions in a logical order.

Although the activity was beneficial, there were some shortcomings. First, it required much preparation time for the teacher. Second, it was possible for students to copy questions from their classmates. Despite these shortcomings, the students' improvement in speaking could be seen clearly after they finished their first year (see Appendix E).

\section{Conclusion}

The project is still in progress. However, positive feedback from the students and the progress the students have made show that the project is fruitful. To help students practice speaking well, the following points should be considered:

- Guidance for students' speaking practice should be given at the beginning of the course as this will help students save time in finding ways to improve their speaking skills.

- Speaking activities should be appropriate to the students' ability.

- Speaking activities should involve and motivate the students.

- For less-able students, more attention should be paid to correct repetition than to performance skills.

- For more-able students, the proportion of repetition and performance skills should be considered carefully as this influences their motivation in learning speaking.

- Good management of group work helps to achieve the active and equal participation of all students and will help to increase the effectiveness of speaking activities.

Language teachers, like ship captains, should guide their students to the harbor of success. When practice is well planned and combined with hard work and commitment on both sides, students' speaking skills will be improved.

\section{Author Note}

Doan Linh Chi, Department of Foreign Languages, Nha Trang Teachers Training College, Nha Trang, Vietnam

I would like to thank the students of English for Primary School K.35 at Nha Trang Teachers Training College; Ms. Tran Dang Khanh Linh, Head of the English Section; Kathy Hong Oanh Nguyen, Fulbright English Teaching Assistant and CamTESOL co-presenter; and the 2011 CamTESOL Program Committee for selecting this paper for the Presenter Grant.

Correspondence concerning this article should be addressed to Doan Linh Chi, Department of Foreign Languages, Nha Trang Teachers Training College, 01 Nguyen Chanh Street, Nha Trang City, Khanh Hoa, Vietnam. E-mail: linhchi.doan@gmail.com 


\section{References}

Baker, J., \& Westrup, H. (2000). The English language teacher's handbook: How to teach large classes with few resources. London, England: VSO/Continuum.

Brumfit, C. (1984). Communicative methodology in language teaching: The roles of fluency and accuracy. Cambridge, England: Cambridge University Press.

Byrne, D. (1987). Techniques for classroom interaction. Singapore: Longman.

Hadfield, J. (1996a). Advanced communication games. Harlow, England: Addison-Wesley Longman.

Hadfield, J. (1996b). Elementary communication games. Harlow, England: Addison-Wesley Longman.

Hadfield, J. (1996c). Intermediate communication games. Harlow, England: Addison-Wesley Longman.

Harmer, J. (1991). The practice of English language teaching. New York, NY: Longman.

Kayi, H. (2006). Teaching speaking: Activities to promote speaking in a second language. The Internet TESL Journal, 7(11). Retrieved from http://iteslj.org/Techniques/Kayi-Teaching Speaking.html

Le, T. B. T. (2010, September). An action research on the application of cooperative learning to teaching speaking. Paper presented at the International Conference on TESOL, Ho Chi Minh City, Vietnam.

Nation, P. (1989). Group work and language learning. English Teaching Forum, 27(2), 20-24.

Nunan, D. (1999). Second language teaching and learning. Boston, MA: Heinle \& Heinle.

Petty, G. (1993). Teaching today. Cheltenham, England: Stanley Thornes.

Qiangba, Y. (2005). What I have learned from group work. Teacher's Edition, 19.

Renandya, W. (2010, September). Does practice make perfect? Featured speaker at the International Conference on TESOL, Ho Chi Minh City, Vietnam.

Ur, P. (1996). A course in language teaching: Practice and theory. Cambridge, England: Cambridge University Press. 


\section{Appendix A}

\section{Speaking Problems and Suggestions}

\section{List of Common Speaking Problems}

Directions: Please tick the problem(s) you have when learning speaking and write your suggestion(s) next to the problem(s).

\section{My Problems}

My Suggestions

1. I can't remember words / phrases.

2. I usually make grammar mistakes when I speak.

3. I usually make pronunciation mistakes when I speak.

4. I think in Vietnamese and then I translate into English.

5. I don't know how to express my ideas well.

6. I feel shy when I have to speak.

7. I am afraid of making mistakes when I speak.

Table A

Students' Common Speaking Problems and Their Suggestions

\begin{tabular}{|l|l|}
\hline \multicolumn{1}{|c|}{ Problems } & \multicolumn{1}{c|}{ Suggestions } \\
\hline Can't remember words / phrases & $\begin{array}{l}\text { Learn them by heart and use them more } \\
\text { often. }\end{array}$ \\
\hline Make grammar mistakes & $\begin{array}{l}\text { Do more grammar exercises. Practice } \\
\text { grammar structures more in speech. }\end{array}$ \\
\hline Make pronunciation mistakes & $\begin{array}{l}\text { Read aloud the words until you get the } \\
\text { correct pronunciation. }\end{array}$ \\
\hline $\begin{array}{l}\text { Think in Vietnamese and then translate into } \\
\text { English }\end{array}$ & No suggestions \\
\hline Don't know how to express ideas well & No suggestions \\
\hline
\end{tabular}

Note: There is no ranking of the students' problems in Table A. All the students ticked the first five common speaking problems list. They were not asked to number the items from the most to the least problematic. 


\section{Appendix B}

Weekly Student Goals

Week 3 (Unit 2, Conversation 1: Tell me about your family)

Student A

\begin{tabular}{|l|l|}
\multicolumn{1}{|c|}{ Things I Want to } & \multicolumn{1}{c|}{ Things I Want to Correct } \\
\hline $\begin{array}{l}\text { Vocabulary: cousin, nephew, niece, } \\
\text { musician, look alike, married, single, sister- } \\
\text { in-law, brother-in-law, aunt, uncle }\end{array}$ & \begin{tabular}{l}
\multicolumn{1}{c|}{ Plural ending: twins, brothers, sisters } \\
Consonant clusters: youngest, oldest
\end{tabular} \\
Functional structures and expressions & Linking sound: I have two brothers and one \\
- Tell me about your family. & sister. \\
- Do you have any brothers or sisters? & \\
- Have you got any brothers or sisters? & $\begin{array}{l}\text { rd person singular ending: My brother lives } \\
\text { - I have three brothers but no sisters. } \\
\text { - No, I'm an only child. }\end{array}$ \\
- We're twins. & receptionist. \\
- How old is your brother? & \\
- We're the same age. & \\
- He's the same age as me. & \\
- Is your brother single / married? & \\
- Does your brother have any children? & \\
- You look too young to be an aunt. & \\
- He works as a waiter. & \\
\hline
\end{tabular}

Student B

\begin{tabular}{|c|c|}
\hline $\begin{array}{c}\text { Things I Want to } \\
\text { Learn by Heart / Practice More }\end{array}$ & Things I Want to Correct \\
\hline $\begin{array}{l}\text { Vocabulary: look alike, sister-in-law, } \\
\text { brother-in-law } \\
\text { Functional structures and expressions } \\
\text { - No, I'm an only child. } \\
\text { - We're twins. } \\
\text { - We're the same age. } \\
\text { - He's the same age as me. } \\
\text { - You look too young to be an aunt. } \\
\text { - My brothers and my sisters are all younger / } \\
\text { older than me. } \\
\text { - He works as a chef. }\end{array}$ & $\begin{array}{l}\text { Consonant clusters: youngest, oldest } \\
\text { Linking sound: I have two brothers and one } \\
\text { sister. } \\
3^{\text {rd }} \text { person singular ending: My sister works } \\
\text { for a foreign company. She lives in Ho Chi } \\
\text { Minh City with her family. She is married } \\
\text { and has two children. Her husband works as } \\
\text { a pilot. He flies to Ha Noi twice a week. }\end{array}$ \\
\hline
\end{tabular}


Student C

\begin{tabular}{|l|l|}
\multicolumn{1}{|c|}{\begin{tabular}{c}
\multicolumn{1}{|c|}{ Things I Want to } \\
Learn by Heart / Practice More
\end{tabular}} & \multicolumn{1}{c|}{ Things I Want to Correct } \\
\hline $\begin{array}{l}\text { Vocabulary: look alike } \\
\text { Functional structures and expressions } \\
\text { - No, I'm an only child. }\end{array}$ & $\begin{array}{l}\text { Linking sound: I have two brothers and one } \\
\text { sister. } \\
\text { - We're twins. }\end{array}$ \\
- We're the same age. & \\
- He's the same age as me. & \\
- You look too young to be an aunt. & \\
\hline
\end{tabular}




\section{Appendix C}

Common Student Mistakes

\begin{tabular}{|c|c|}
\hline Grammar Mistakes & Pronunciation Mistakes \\
\hline $\begin{array}{l}\text { - incorrect verb tense forms / incorrect } \\
\text { - use of tenses } \\
\text { - incorrect use of prepositions } \\
\text { - missing prepositions } \\
\text { - incorrect use of articles }\end{array}$ & $\begin{array}{l}\text { - missing the ending sounds in plural nouns } \\
\text { (e.g., oranges = orange, apples = apple) } \\
\text { - missing third-person singular ending of the } \\
\text { verb in the simple present tense (e.g., likes } \\
\text { = like, watches = watch) } \\
\text { - missing ending sound of regular verbs in } \\
\text { the simple past tense or in the past } \\
\text { participle form (e.g., stopped = stop, } \\
\text { stayed = stay) } \\
\text { - missing certain sounds in final clusters } \\
\text { (e.g., film: /film/ = /fim/, text: /tekst/ = /tek/) } \\
\text { - inserting a vowel sound into a consonant } \\
\text { cluster (e.g., /spi:k/=/s...pi:k/) } \\
\text { - adding hissing sound/s/ to all the words } \\
\text { (e.g., I go to school = l/s/go/s/to/s/ } \\
\text { school/s/) } \\
\text { - no linking sounds } \\
\text { - incorrect intonation }\end{array}$ \\
\hline
\end{tabular}

Note. The functional patterns presented in the speaking course book cover the grammar points listed in the table.

\section{Appendix D}

\section{Activities for the First and Second-Year Students}

\begin{tabular}{|c|c|}
\hline Activities for First-Year Students & Activities for Second-Year Students \\
\hline \multicolumn{2}{|c|}{$\begin{array}{c}\text { Brainstorming } \\
\text { Information Gap } \\
\text { Storytelling } \\
\text { Story Completion } \\
\text { Reporting } \\
\text { Interviews } \\
\text { Picture Narrating } \\
\text { Role-Play } \\
\text { Talks on Topics }\end{array}$} \\
\hline $\begin{array}{l}\text { Playing Cards } \\
\text { Find the Difference } \\
\text { Picture Describing }\end{array}$ & $\begin{array}{l}\text { Discussions } \\
\text { Stage Plays } \\
\text { Simulations }\end{array}$ \\
\hline
\end{tabular}




\section{Appendix E}

\section{Results of the $1^{\text {st }}$ and $2^{\text {nd }}$ End-of-Term Speaking Exams (First Year)}

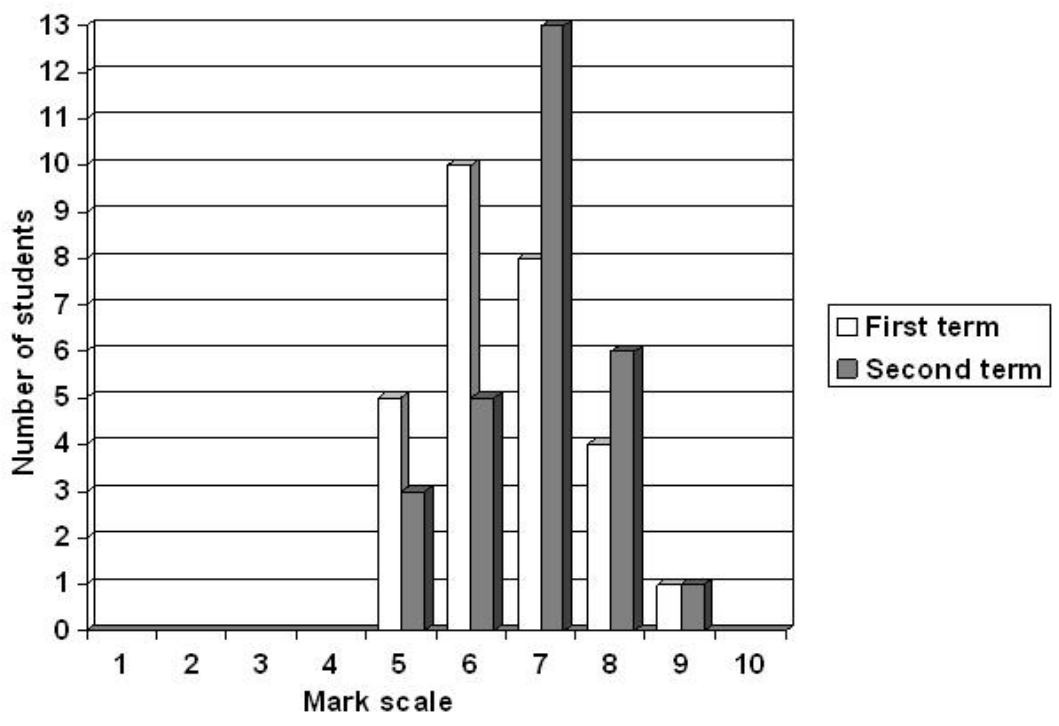

Figure $E$. In the first term the number of students receiving marks of 5 and 6 in speaking test exceeded the number of students receiving marks of 7, 8 and 9 . In the second term the result was opposite. At the college, in the students' study records, decimal numbers were rounded up or down to the nearest whole numbers.

The examiners of the speaking test were the teachers of speaking; one was the researcher, and the other one was chosen at random. These teachers supervised and were interviewers in both the first and second term tests.

The speaking task had two parts: role-plays ( 8 marks) and interviews (2 marks). In role-plays based on learnt structures and topics, each pair of students was asked to sit separately. They had three minutes to read the requirements on the cards for preparation, and then they were asked to perform their conversations in pairs. The students' role-plays were assessed on the following criteria: ideas and length (2 marks), accuracy (1 mark each for pronunciation, intonation, grammar, and learnt structures) and fluency and manner of speaking ( 1 mark each for turn-taking and natural / fluent speech). In interviews, the examiners asked each student two questions ( 1 mark for each answer) related to learnt topics. These questions were not related to the topic of the presented role-play; for example, if Students A and B had to perform a role-play in a restaurant, then the questions for them would be about their future plans or intentions. The students had no time to prepare. The answers were assessed on (a) ideas (0.25), (b) language patterns (0.25), (c) pronunciation (0.25), and (d) quick answer (0.25). In cases where the questions had to be repeated, no mark was given for (d). There was no second repetition of the questions. 